Justice in a new world: negotiating legal intelligibility in British, Iberian, and Indigenous America. Edited by Brian P. Owensby and Richard J. Ross, New York, New York University Press, 2018. [Book review]

\title{
Tuori, Kaius
}

2019

Tuori , K 2019 , ' Justice in a new world: negotiating legal intelligibility in British, Iberian, and Indigenous America. Edited by Brian P. Owensby and Richard J. Ross, New York, New York University Press, 2018. [Book review] ' , Comparative legal history, vol. 7 , no. 2 , pp. 225-227 . https://doi.org/10.1080/2049677X.2019.1685747

http://hdl.handle.net/10138/327395

https://doi.org/10.1080/2049677X.2019.1685747

cc_by_nc_nd

acceptedVersion

Downloaded from Helda, University of Helsinki institutional repository.

This is an electronic reprint of the original article.

This reprint may differ from the original in pagination and typographic detail.

Please cite the original version. 
There is a reason why publishing houses do not like conference volumes. More often than not they are collections of disjointed essays, selected not primarily for quality but rather based on who was able to meet the deadline, held together by an introduction seeking to lay out some common themes in a heroic yet futile effort, much like herding kittens. The volume at hand, Justice in a New World, has this pedigree, but has it managed to avoid these pitfalls, to get its ducks in a row?

For this journal, the theme is extremely pertinent. The encounter between colonizers and indigenous peoples around the world between what has been earlier called somewhat ill-fittingly the age of discovery and the nineteenth century colonialism has been increasingly understood as a legal process. What is more, pioneering works such as those by Lauren Benton, Anthony Pagden, Mahmood Mamdani or Stuart Banner have often taken a comparative character. However, these comparisons have been limited mainly to the English-speaking world, colonial settler states in North America, Australia, New Zealand and South Africa. It is perhaps a testament to the richness of the material that is available that comparative studies have rarely ventured outside of this area. In fact, the Spanish and Portuguese colonial empires tend to feature in the standard textbooks merely as backdrops to the $16^{\text {th }}$ century discussions such as the Valladolid debates. This disappearance is somewhat strange and may best be attributed to the limitations imposed both by language barriers and scholarly conventions.

This disjunction is the overarching theme of the book. It seeks to join together in a comparative enterprise the experiences in both the North and the South of America, mainly the Spanish and the English legal policies and practices. The book draws a sharp distinction between the English notion of separation and the Spanish notion of inclusion. The British operated through the recognition of indigenous communities as quasi-sovereign entities that were on the other hand legally autonomous but on the other incapable of appealing to the British court system for recourse. The Spanish, in contrast, sought to define indigenous communities as subjects of the crown, leading to contentions on property rights, equality and so forth. While the British policy of separation meant that indigenous peoples were legally aliens, in Spanish colonies a new whole body of law, the derecho indiano, emerged to cater to the issues that emerged from the inclusion of often very different indigenous communities to the Spanish colonial regime. Comparison between these two very different and sometimes interlinked colonial legal regimes would offer rich rewards

Thus, the collection is both relevant and timely, coming with a novel comparative theme. As always, comparative studies between very different phenomena with different contexts has its pitfalls, risking becoming a comparison between kittens and ducks. In the current volume, much of the work of pulling strings together is done by the extensive introduction (pp. 1-58). In the introduction, Owensby and Ross seek to describe the British and the Spanish policies and their differences, the Stand der Lehre in the field and the notion of intelligibility that looks large in their view of the field. The text is very fluent and gives a good outline of the field and central studies in it, leading this reviewer to consider assigning it for students. The drawback of all this is naturally the slight descriptiveness. 
The substantive chapters are divided into three sections, all of which seek to incorporate studies from both North and South. The first section examines the attempts and dialogue between the indigenous and the settler, between vastly different cultures and land rights regimes. Tamar Herzog discusses the miscommunication through the examination of acts such as gift exchanges, negotiations and rituals between the indigenous peoples and the Portuguese settlers. The overarching theme is that of misunderstandings, miscommunication and distrust that underlie the contractual relations and the treaties that were made in the seventeenth and the eighteenth centuries. Jenny Hale Pulsipher offers a similarly wide-ranging treatment of the negotiations and treaties between Indian tribes and English settler communities in the seventeenth century, resulting in land sales and transfers under expanding settler activities. While most of these transactions were predatory in nature, Pulsipher seeks to trace strategies in which Indians sought to utilize both Indian and English legal notion to fight dispossession. Graig Yirugh takes the story to the eighteenth century in North America, examining the treaty between the Iroquois and the English, seeking to examine the arguments on both sides over rights and sovereignty. Karen Graubart returns the argument to the Spanish sphere of influence and the sixteenth and seventeenth centuries. Her focus is on rural Peru and the jurisdiction over indigenous communities and their property rights, drawing on local disputes.

In the second section, the overarching theme is that of conflicting conceptions of justice between the indigenous and the settler. In one of the few comparative chapters, Bradley Dixon compares English sixteenth century Virginia and Spanish Florida in the seventeenth century. In both cases, there existed a separation, in Virginia between the two sovereign communities and in Florida between the two republics, the republic of Spaniards and the republic of Indians, which were vassals to the crown. In both cases, the narrative is that of the gradual erosion of the rights of the indigenous communities. Nancy Gallman and Alan Taylor move the discussion towards criminal cases and the notions of jurisdiction and sovereignty. Their study begins on eighteenth century North America and the incursion of coercive state power to the Indian sovereignties, but continues with Spanish Florida, focusing on the delicate interplay between revenge and jurisdiction in cross-cultural crime. Marcela Echeverri pushes the timeframe to the early nineteenth century and New Granada, roughly current Columbia, Venezuela and environs. This chapter incorporates the exciting theme of the reception of ideas of independence and citizenship in indigenous communities during the struggle for independence.

The third section offers two chapters of conclusions, first by Lauren Benton and then by Daniel Righter. Benton reframes the discussion to the Atlantic world and legal policies, beginning somewhat illogically from Australia. However, the theme of her paper is the disjunction between intelligibility and understanding and their implication in understanding the colonial encounters. In it, she urges for the study of not only understandings but also ignorance and wilful misunderstandings as fruitful ways of appreciating the historical phenomena and the ambiguities that were so prevalent. Daniel Richter's concluding section approaches the disjunction between the indigenous and the settler through the concepts of intelligibility and incommensurability. What this seeks to convey is that the problem was not purely that of understanding, but rather that the worlds that collided, both the cultural and the legal (if one wants to make that distinction) were devoid of not only common language but also common metrics, of meeting points. Thus the issue of intelligibility was not only an issue of talking past one another, but not really grasping what the other was. 
In conclusion, his is a theoretically and analytically ambitious edited volume on a crucial theme, expanding scholarship in a field that is rapidly advancing. Instead of purely legal analysis, the collection seeks to incorporate concepts and themes of contemporary cultural studies, from code switching to incommensurability. All the studies are sections of studies founded on archival work and a deep commitment to the field. This is also a bit of the problem in the sense that the theoretical and abstract way of discussing the matters in the introduction and in the concluding chapters do not necessarily meet with the very meat and bones kind of discussion in the substantive chapters, being as they are very solidly based on archival work and within their respective research areas. All in all, a work that is required reading for all interested in comparative studies of law, especially that of law and colonialism.

Kaius Tuori

University of Helsinki 